\title{
The Skill Profile of
}

Central Bankers and Supervisors

By

Charles Goodhart,

Dirk Schoenmaker

and

Paolo Dasgupta

DISCUSSION PAPER 377

April 2001

\section{FINANCIAL MARKETS GROUP}

AN ESRC RESEARCH CENTRE

\section{LONDON SCHOOL OF ECONOMICS}

Any opinions expressed are those of the author and not necessarily those of the Financial Markets Group. 
By

\title{
Charles Goodhart \\ Financial Markets Group \\ London School of Economics
}

\author{
Dirk Schoenmaker \\ Financial Markets Policy Department \\ Ministry of Finance (NL) \\ and \\ Paolo Dasgupta \\ Financial Markets Group \\ London School of Economics
}

April 2001

JEL Codes: G28, E58, O40.

Using a new database covering some 91 supervisory agencies, this paper examines how important various skilled experts are in the regulatory process and the relative usage of different kinds of such experts. We seek to explore what kind of perspective supervisors in different institutional settings may adopt: a macro-oriented perspective or a more micro-approach? The answer to this question is relevant, as there is evidence that many financial crises have been macro-induced.

It is found that central banks employ more economists and fewer lawyers in their supervisory/financial stability wing than non-central bank supervisory agencies. Next, there are significant economies of scale in financial supervision, though this can be measured by several alternative variables (e.g. the relative scale of bank intermediation). Finally, there do not appear to be major economies of scope. A more

\footnotetext{
- The authors would like to thank Joe Ganley for valuable research assistance. The views in this paper are those of the authors and not necessarily those of the Ministry of Finance in the Netherlands. Goodhart and Schoenmaker designed the exercise; Dasgupta did the bulk of the numerical work. Correspondence to: d.schoenmaker@minfin.nl.
} 
complex financial system with a well-developed stock market would need both more supervisors as well as more skilled ones. 
In an earlier paper (Goodhart and Schoenmaker, 1995), we observed a trend towards separation between monetary policy and supervisory agencies. A major reason is that if taxpayers were seen to be potentially liable during a crisis, there would be a demand for more direct political control over supervision. Subsequently, some central banks have lost their supervisory powers, notably the Bank of England.

A key question in the ongoing debate on separation (e.g. Peek, Rosengren and Tootell, 1999) is which institutional structure will deliver better results. It is difficult to answer this question by inspecting the historical record (i.e. evidence of outputs). This is partly because financial crises, though regrettably more frequent in recent decades, remain rare events and are often triggered by factors quite independent of the organisational structure of supervision. The literature on financial crises (e.g. Caprio and Klingebiel, 1997; Kaminsky and Reinhart, 1999) has not explored the relationship between institutional structure and the likelihood of severe financial sector problems or of a full-blown financial crisis. 1 In this paper, we inspect what staffing and expertise institutions employ (i.e. evidence of inputs) in an attempt to shed more light on the question of which structure may do better. The study involves a quantitative evaluation of the academic and professional skills of the supervisory staff at central banks and supervisory agencies. This new area of research is based on a unique data set.

In particular, we seek to explore what kind of perspective supervisors in different institutional settings may adopt: a macro-oriented perspective or a more micro-approach? The answer to this question is relevant, as there is evidence that many financial crises have been macro-induced (e.g. Hellwig, 1995; Lindgren, Garcia and Saal, 1996; Kaminsky and Reinhart, 1999). Examples are the US Savings \& Loans debacle (interest rate shock), the Scandinavian banking crisis (recession) and the UK secondary banking crisis (property prices). These macro-related causes are often intertwined with micro-related factors. The banking problems in Scandinavia, for example, may have been triggered by a recession in the late eighties/early nineties, but liberalisation of the financial sector in the mid eighties, in the absence of proper risk measurement and control mechanisms at banks, as well as lack of risk awareness at supervisory agencies, may have contributed to an unchecked boom in lending.

This cross-country survey of the skill profile of supervisory staff should help to provide an insight into two additional issues. First, are 
market employ more, or a different type of, supervisors than a country with a financial system that is mainly bank-intermediated?

The paper is organised as follows. The next section provides a detailed description of the database. The database incorporates data on the number of supervisors as well as the number and type of professional experts (economists, financial experts, lawyers). Data were gathered from 91 institutions covering 57 separate countries. The third section presents the empirical results. Regressions are run with the number and type of staff as dependent variables and the role of the institution (central bank, sole supervisor, joint supervisor, no supervisor at all) as explanatory variables. The fourth section discusses the implications of the results for the institutional structure of supervision. The conclusions are presented in the final section. In particular, it is found that central banks employ considerably more economists and fewer lawyers in their supervisory/financial stability wing than non-central bank supervisory agencies.

This paper focuses on analysing the numbers and the nature and level of expertise of the staff employed by almost 100 financial supervisory agencies around the world. This includes central banks, bank, securities and insurance supervisors, irrespective of whether the countries have opted for a unified 'megasupervisor' structure or, alternatively, a number of joint supervisors. The study involves a quantitative evaluation of the academic and professional skills of those employed by these bodies, gathered from the responses to a questionnaire. The data refer to the supervisory departments of these bodies. Staff employed in the monetary wing of central banks is thus excluded. Data on staff in the supervisory and financial stability sections of central banks are difficult to separate. Moreover, these sections tend to use each other in practice. Supervisors would, for example, make use of a macro-economic outlook for the financial system prepared by the financial stability people.

The questionnaire has been sent to some 250 supervisory agencies mentioned in 'How countries supervise their banks, insurers and securities markets' (Courtis, 1999). Some 170 replies were received, which produces a rather good response rate of $68 \%$. But several of these replies did not give sufficient quantitative data to include in the statistical exercises in section 3. Usable data were obtained from 91 institutions covering 57 separate countries, producing an effective response rate of $37 \%$. Naturally, as we seek to examine a widening range of possible explanatory variables, to discover the factors determining the use of professional skilled inputs by supervisory agencies, the sample sizes tend to drop.

\subsection{Raw data}

The first part of the questionnaire was intended to discover the supervisory tasks for which each institution has been responsible (i.e. whether systemic stability, prudential supervision and/or conduct of business). It also asked about the make-up of the financial sector in each country, and by doing so to 
shed light, implicitly, on the area of the financial sector each institution has to supervise (i.e. whether it regulates banks, securities firms, insurance houses, markets, independent advisers, etc.). This information determines whether the agency is a 'mega-supervisor' (i.e. a sole supervisor), a joint supervisor, or has no supervisory mission at all.

The second part enquired more specifically about the academic and professional qualifications of the staff employed by the regulatory bodies. The agencies were asked to quantify the number of staff specialising in the different professions (lawyers, accountants, economists, financial experts, others), and how many have had some commercial experience (i.e. how many had worked in the private sector beforehand). The final question, concerning staff qualifications, tried to establish the number of experts working at the agency. Experts are defined as staff with the equivalent of a university Master's degree or above. On several occasions, it was necessary to write back asking for more specific information, especially in relation to the commercial experience of the staff and to their academic qualifications.2 $\mathrm{A}$ copy of the questionnaire is included in Appendix 1. It should be noted that there are other staff characteristics that have not been covered in the survey, but may play an important role (such as the length of professional experience of the staff or differences in higher education systems).

In order to obtain a picture of the economic position and stage of financial development of those countries whose agencies responded, a set of 12 variables was obtained from secondary sources (see Table 5 in section 3.2). Inter alia, these data include variables such as GNP, M2 as a measure of broad money, stock exchange capitalisation as well as the number of regulated banks of each country. These variables are, ex ante, envisaged either as potential deflators or as potential explanatory variables for the data received from the regulators.

\subsection{Constructing the database}

The data come from countries of very different sizes, from tiny (Cayman Islands) to huge (USA), and at very differing stages of financial development. Clearly, the raw (absolute) figures by themselves are not very meaningful. So the first step of the exercise is to establish a set of economic variables, which could represent feasible deflators for the basic data. The use of deflators is necessary to make comparisons between the institutions more consistent, as it is evident that supervisory agencies belonging to smaller countries are likely to employ fewer qualified staff than larger countries in absolute terms. The variables to be explained were deflated respectively by M2, GNP and the number of banks operating in the respective countries. The bank denominator was subsequently abandoned due to a lack of available data for a significant number of countries. The results of the regressions with M2 as deflator and with GNP as deflator make little difference. We proceed with $\mathrm{M} 2$, which is a good indicator of the size of the monetary/financial system.3

2 Moreover, many supervisory bodies are currently undergoing significant structural changes, and are at different stages of transition, with a rapid turnover of staff, making it hard for them to provide such data.

3 The results of the regressions with GNP as deflator are available on request from the authors. 
The basic data series are turned into a set of ratios, where the numerator is derived from the survey, and the denominator is M2 or another survey variable. This provides us with a set of eight ratios, as presented in Table 1. The first three ratios relate to the number of regulators in supervisory agencies and the number of experts among them. The fourth ratio presents the number of regulators with commercial experience. The final four ratios shed light on the composition of experts. Most supervisory agencies have provided usable data on lawyers, economists and financial experts. However, too few agencies actually specify the number of accountants working for them. Other professional experts are omitted because conclusions, drawn from this variable, would not be very meaningful, due to the lack of specificity in professional terms. The ratios of lawyers (5) and economists and financial experts (7) to total number of regulators show how important various experts are in the regulatory process, while the ratios of lawyers (6) and economists and financial experts (8) to total experts show the relative usage of different kinds of experts.

\begin{tabular}{|c|c|c|}
\hline & & Regs/M2 \\
\hline 1. & Total Number of Regulators/M2 & Experts/M2 \\
\hline 2. & Total Professional Experts/M2 & Experts/Regs \\
\hline 3. & Total Professional Experts/Total Number of Regulators & Commercial/Regs \\
\hline 4. & Commercial Experience/Total Number of Regulators & L/Regs \\
\hline 5. & Lawyers/Total Number of Regulators & (E + F)/Regs \\
\hline 6. & Lawyers/Total Professional Experts & $($ E + F)/Experts \\
\hline 7. & (Economists + Financial Experts)/Total Number of Regulators & (Economists + Financial Experts)/Total Professional Experts \\
\hline 8. & (Ex)
\end{tabular}

Closer inspection shows that the distributions of the ratios are not normal, and that there are some extreme outliers (see Appendix 2 for the summary statistics). Quite often, the same respondent is an outlier in several cases. In a few cases, it is not clear whether the respondent has replied accurately, particularly in those cases where the number of experts is higher than the number of regulators. This implies the number of experts provided represents the total number of experts in the agency, instead of those employed only in the respective regulatory divisions, as asked (see the questionnaire in Appendix 1). Clearly, there is also some fuzziness in the definition of experts whereby Master degrees and above are not equivalent in each of the countries analysed. Moreover, there may well be some divergence between the ways that the various agencies measure and assess 'commercial experience'. Finally, some inconsistencies may be related to the actual work performed by the agency. The size and professional level of staff in a supervisory agency depend, for example, on whether the agency conducts off-site or on-site supervision (agencies that focus on on-site supervision require more staff than those that work primarily through off-site supervision or that rely on the work of external auditors). 
We next divide our sample into several categories, i.e. whether the respondent was a Central Bank or not; in the OECD or not; and what type of supervision it was responsible for, i.e. systemic, prudential and/or conduct of business. What we want to discover in this exercise is what are the main factors, besides pure size -which we hope is controlled by the deflator-, which influence the input of professional skills into the supervisory process. One obvious factor is the institutional status; we seek to quantify this in a variety of ways. The variables listed below are used as dummies, reflecting the institutional functions of the regulatory bodies. The agencies analysed are classified according to whether:

- $\quad$ they are a Central Bank or not (Central Bank);

- $\quad$ they are a sole supervisor (Sole), joint supervisor (Joint), or not a supervisor at all (Not Supervisor);

- $\quad$ they are responsible for systemic stability (Systemic), prudential supervision (Prudential), conduct of business (Conduct) or a combination of these.

\begin{tabular}{|c|c|c|}
\hline & & \\
\hline 1. & OECD Central Banks, Sole Supervisors & 9 \\
\hline 2. & Non-OECD Central Banks, Sole Supervisors & 27 \\
\hline 3. & OECD Central Banks, Joint Supervisors & 1 \\
\hline 4. & Non-OECD Central Banks, Joint Supervisors & 10 \\
\hline 5. & OECD Central Banks, No Supervisory Role & 1 \\
\hline 6. & Non-OECD Central Banks, No Supervisory Role & 6 \\
\hline 7. & OECD Non-Central Banks, Mega-Supervisors & 0 \\
\hline 8. & Non-OECD Non-Central Banks, Mega-Supervisors & 29 \\
\hline 9. & OECD Non-Central Banks, Multiple Agencies & 1 \\
\hline 10. & Non-OECD Non-Central Banks, Multiple Agencies & 91 \\
\hline Total & & \\
\hline
\end{tabular}

Table 2 shows that for OECD countries there is a balance between the number of Central Banks responsible for sole/joint (16) or no supervision (10). This might reflect the trend in OECD countries towards removing supervisory powers from Central Banks, allowing them to focus on inflation targets, and passing such powers to 'mega-supervisors' or 'multiple agencies', which are also now quite numerous. In contrast, non-OECD countries mostly seem to rely on their Central Banks to supervise financial institutions (28 sole/joint supervision compared to 1 no supervision), besides conducting their traditional task of setting monetary policy.

To give an overview of the data, Table 3 presents the average ratio for each category. Data are provided for four ratios: total number of regulators deflated by $M 2$, regulators with commercial experience to total number of regulators, lawyers to total experts and economists and finance experts to total experts. The 
number of regulators deflated by M2 seem to be higher in non-OECD countries.4 To pick up any structural differences, a dummy for OECD is incorporated in the regression analysis (see section 3.2). The average ratio of regulators with commercial experience is higher at multiple agencies, suggesting that these specialist agencies mainly hire employees with private sector experience. The average ratio of laywers to experts is lower in central banks than in separate supervisory agencies, while the number of economists and finance experts is higher.

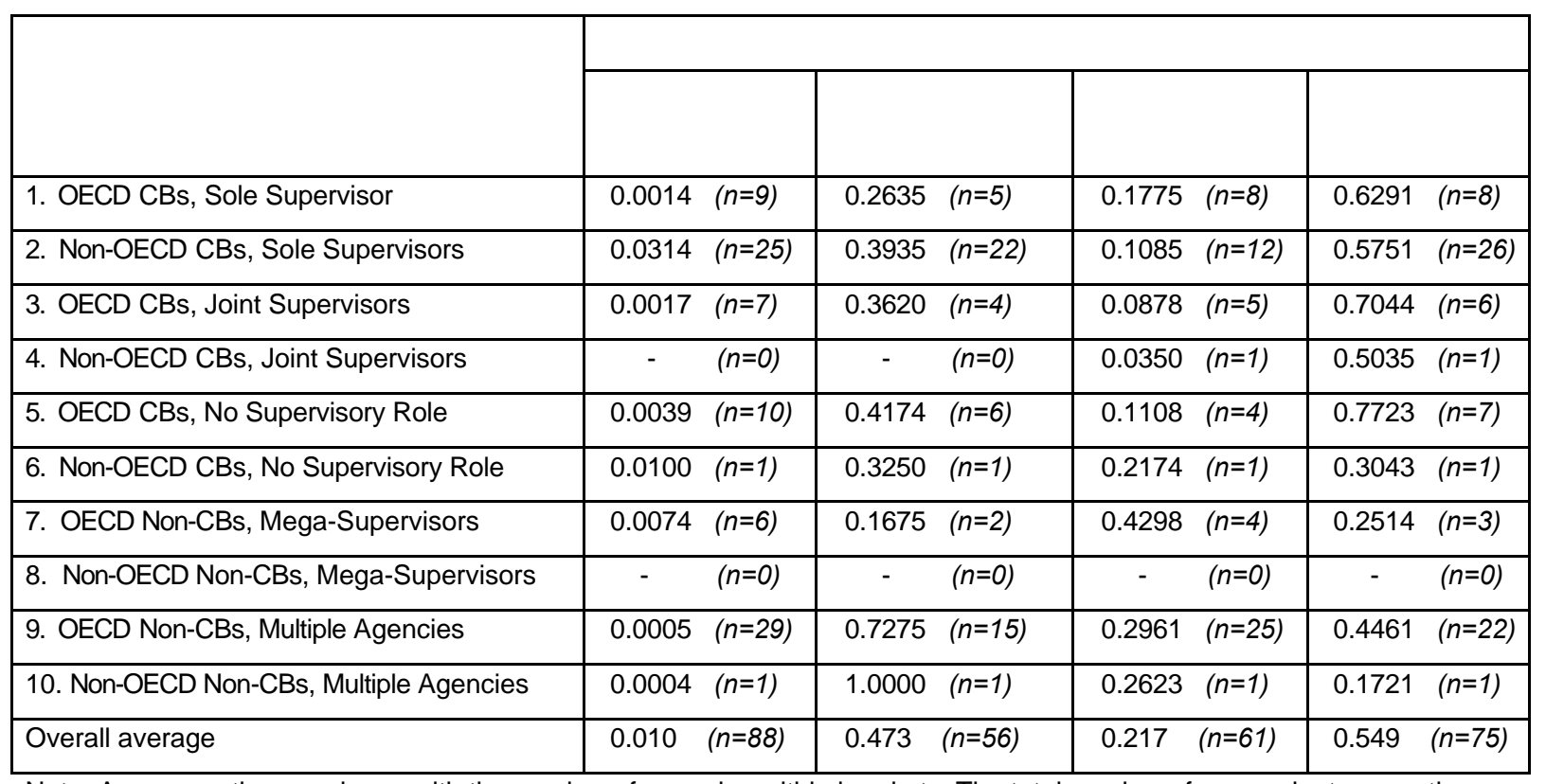

Note: Average ratios are shown with the number of agencies within brackets. The total number of respondents per ratio can be lower as not all of the 91 respondents completed all questions in the survey.

\subsection{The effect of supervisory role on skills}

The first stage of the empirical test was to run regressions with the eight ratios as dependent variables and a set of institutional variables as explanatory variables. The full set of institutional variables comprises both the supervisory role of each agency (sole supervisor, joint supervisor, or not supervisor at all) and the duty (systemic stability, prudential supervision, and/or conduct of business). GNP per head (PPP, 1998 data; see Table 5) is incorporated as a plausible economic variable to utilise as an explanatory element for the ratios calculated. GNP per head measures the relative income level and, as such, can be expected to have a significant effect on the utilisation of professionally skilled staff by the

4 Surprisingly, the average ratio of Regs/M2 is higher for OECD Central Banks with no supervisory role $(0.0039)$ than for OECD Central Banks which are sole supervisor (0.0014) or joint supervisor (0.0017). Closer inspection of the underlying data learns that this figure is due to the inclusion of South Korea, which is in a process of transition. The Bank of Korea (CB) still employs many regulators while supervision was hived off to a newly established mega-supervisor in 1998. Excluding South Korea, the average ratio is 0.0006 . 
respective regulatory agencies. A country with greater income per capita implies that its regulatory agencies can afford a higher level of qualified staff, possibly with a wider and deeper range of professional skills, at the same time.

The basic equation is specified with the supervisory role (see Appendix 3 for supervisory duty):

$$
\text { Ratio }_{i}=\alpha+\beta \text { Central Bank }_{i}+\delta_{1} \text { Sole }_{i}+\delta_{2} \text { Joint }_{i}+\delta_{3} \text { Not Supervisor }_{i}+\gamma \text { GNP/head }_{i}+\varepsilon_{i}
$$

where Central Bank $k_{i}$ is the dummy for supervisory agency $i$ being a central bank; Sole $e_{i}$ for being solely responsible for supervision; Joint ${ }_{i}$ for being jointly responsible; Not Supervisor ${ }_{i}$ for being not a supervisor at all; GNP/head denotes GNP per head of the country of location; $\varepsilon_{i}$ is the error term.

As already noted the data set includes several outliers. To assess which agencies are outliers, two methods are used: i) looking at the initial ratios and examining whether individual agencies have values of these ratios which are several standard deviations from the mean, ii) looking at the residuals from the regressions and observing whether some particular residuals are outliers. Certain supervisory agencies appear to be very oddly placed compared to the majority of agencies that cluster around a certain mean value. However, removal of the outliers has only a marginal impact on the results, which is comforting. Nevertheless, logs are used for the dependent variables to lessen the non-normality of the underlying database, which has a few outliers exhibiting much higher ratios than the norm.5 The results of the regressions are shown in Table 4.

\begin{tabular}{|c|c|c|c|c|c|c|c|}
\hline$(n=76)$ & $\begin{array}{c}* * * \\
(-4.16)\end{array}$ & $\begin{array}{c}* * * \\
(2.73)\end{array}$ & $(0.08)$ & $\begin{array}{c}\star \star \\
(-2.28)\end{array}$ & $\begin{array}{c}* * \\
(-2.41)\end{array}$ & $\begin{array}{c}* * * \\
(-8.08)\end{array}$ & 0.653 \\
\hline$(n=75)$ & $\begin{array}{c}\star \star * \\
(-3.25)\end{array}$ & $(0.96)$ & $(0.38)$ & $(-1.45)$ & $(-1.55)$ & $\begin{array}{c}* * * \\
(-6.48)\end{array}$ & 0.507 \\
\hline$(n=76)$ & $\begin{array}{c}* \\
(-1.98)\end{array}$ & $(-1.41)$ & $\begin{array}{c}* \\
(1.68)\end{array}$ & (1.01) & $(1.40)$ & $(0.16)$ & 0.005 \\
\hline$(n=55)$ & $\begin{array}{c}\star * \\
(-2.44)\end{array}$ & $(-0.71)$ & (1.53) & (1.12) & $(0.56)$ & $(-0.10)$ & -0.032 \\
\hline$(n=61)$ & $(-1.31)$ & $(-4.90)$ & $(0.08)$ & $(0.01)$ & $(0.67)$ & $(-0.72)$ & 0.267 \\
\hline$(n=55)$ & $(-2.21)$ & $(-4.89)$ & $(0.82)$ & $(0.43)$ & $(0.53)$ & $(0.30)$ & 0.374 \\
\hline
\end{tabular}

5 We also ran all the regressions with the dependent variables in absolute form, available on request from the authors. The main results remain much the same. 


\begin{tabular}{|c|c|c|c|c|c|c|c|}
\hline$(n=74)$ & $(-2.16)$ & $(-0.17)$ & $(0.76)$ & $(0.79)$ & (1.22) & $(1.03)$ & -0.004 \\
\hline$(n=66)$ & $(-3.02)$ & (3.33) & $(1.00)$ & (1.55) & (1.94) & $(-1.16)$ & 0.281 \\
\hline \multicolumn{8}{|c|}{ 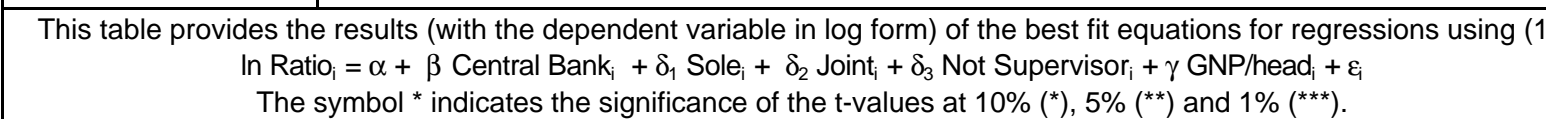 } \\
\hline
\end{tabular}

What light do these regressions throw on the determinants of the ratios, remembering the qualification that the non-normality of our sample makes OLS techniques less reliable? First, we examine the determinants of the number of staff in the supervisory agencies. Regulators (supervisors) are interpreted as staff working in specific divisions or units of a public institution, monitoring and, in many cases, supervising, financial institutions, to avoid different types of financial risks from damaging the economy. As might be expected, the number of regulators is least when the agency is not responsible for supervision at all, and less when the agency is a joint regulator than a sole regulator. Although the coefficients here have the ordering that would be expected, the differences are less significant than might have been expected. The difference between the number of regulators when there is no responsibility at all is indeed barely (and insignificantly) less than in the case with joint responsibility. Next, perhaps rather surprisingly given their various responsibilities, Central Banks employ more regulators than other supervisory agencies. We wonder whether this could be due to the stronger funding position of Central Banks. It would take further research (e.g. looking at salary levels), however, to examine this hypothesis fully.

The effect of GNP per head is negative, at the $1 \%$ level of significance. We are strongly inclined to interpret this as evidence of economies of scale in supervision. It does not take ten times as many supervisors to inspect a bank of $£ 20$ bn as one of $£ 2$ bn, nor - though the economies may be less in this case - when there are 200 rather than 20 banks to be estimated. In the next section (3.2), when we examine other indicators of the scale of the supervisory task, we shall try to throw further light on the extent and determinants of economies of scale.

Moving on to the numbers of experts employed, there is no evidence that Central Banks hire more experts than non-Central Banks, unlike the case of total regulators. Again, GNP per head remains a strongly negative factor, implying some economies of scale. The ratio of experts to total regulators seems not to be determined by this set of institutional variables. Overall, the fit of this equation is much poorer than those of the previous regressions. Alas much the same lack of explanatory power appears when we examine the employment of those with prior commercial experience in the private sector in proportion to total regulators. So the proclivity to hire those with private sector commercial experience must depend on other factors. 
We then turn to an examination of the factors determining the hiring of experts with differing professional skills. The two categories that we could examine, with a sufficiently large number of responses, are lawyers on the one hand, and economists (plus finance experts) on the other. The results are quite clear and strong. The main determinant is whether the agency is a Central Bank, or not. Central Banks hire economists and finance experts, but many fewer lawyers (the coefficients in equations 5 and 6 are -0.60 and -0.46) in their supervisory/financial stability wing. Non-Central Banks have the reverse tendency. Central Banks are economics-driven; non-Central Banks are law-driven. This claim may appear to be challenged for the ratio $(E+F) /$ Regs (equation 7 in Table 4). We explain this tentatively on the grounds that Central Banks hire more regulators than non-Central Banks, so the ratio of $(E+F) /$ Regs remains largely unchanged, with both $(\mathrm{E}+\mathrm{F})$ and Regs rising pari passu. There is no significant effect of GNP per head.

The regressions with supervisory duties are shown in Appendix 3 (Table C). As would be expected, those institutions focusing on prudential supervision employ fewer lawyers, but the effect is far smaller than for central banks. However, they (other than central banks) do not employ more economists. Agencies responsible for conduct of business employ fewer economists.

\subsection{The effect of economic variables on skills}

The previous section is restricted to including a single economic variable, GNP per head, in the regression analysis. As earlier noted, this variable is frequently significant, and when significant usually negative, probably indicating the existence of economies of scale in the operation of regulation/supervision. Of course, many other relevant economic variables might influence the employment of (professionally skilled) regulators. To examine this latter more thoroughly we collected data on 11 additional cross-country sets of variables. These are shown in Table 5.

\begin{tabular}{|c|c|c|c|c|}
\hline 1 & $\begin{array}{l}\text { PPP GNP/head, US\$, } \\
1998\end{array}$ & $\begin{array}{c}\text { World Bank, World Development } \\
\text { Report, 1999/2000, Table } 1 \text { \& } \\
\text { World Factbook } 2000\end{array}$ & 58 & $\begin{array}{l}\text { A measure of the relative } \\
\text { wealth of the country. }\end{array}$ \\
\hline 2 & PPP GNP, US\$ mln, 1998 & $\begin{array}{c}\text { World Bank, World Development } \\
\text { Report, 1999/2000, Table } 1 \text { \& } \\
\text { World Factbook } 2000\end{array}$ & 58 & $\begin{array}{c}\text { Wealth effect should be } \\
\text { positive on absolute numbers, } \\
\text { but may be negative on ratios } \\
\text { because of economies of } \\
\text { scale. }\end{array}$ \\
\hline 3 & $\begin{array}{c}\text { Narrow Money (M1), } \\
\text { US\$ mln }\end{array}$ & $\begin{array}{l}\text { IMF International Financial } \\
\text { Statistics, } 1998 \\
\end{array}$ & 55 & \begin{tabular}{|c|}
$\begin{array}{c}\text { A measure of the size of the } \\
\text { system. }\end{array}$ \\
\end{tabular} \\
\hline 4 & $\begin{array}{l}\text { Narrow Money (M1) } \\
\text { Per Head, US\$ }\end{array}$ & $\begin{array}{l}\text { IMF International Financial } \\
\text { Statistics, } 1998 \\
\end{array}$ & 55 & $\begin{array}{l}\text { A measure of monetary } \\
\text { wealth. }\end{array}$ \\
\hline 5 & $\begin{array}{l}\text { Money stock - Broad } \\
\text { (M2), US\$ mln }\end{array}$ & $\begin{array}{l}\text { IMF International Financial } \\
\text { Statistics, } 1998\end{array}$ & 56 & $\begin{array}{c}\text { A measure of the size of the } \\
\text { system. }\end{array}$ \\
\hline 6 & $\begin{array}{l}\text { Broad Money (M2) } \\
\text { Per Head, US\$ }\end{array}$ & $\begin{array}{l}\text { IMF International Financial } \\
\text { Statistics, } 1998\end{array}$ & 56 & $\begin{array}{l}\text { A measure of monetary } \\
\text { wealth. }\end{array}$ \\
\hline 7 & OECD membership & OECD & 58 & A rough measure of \\
\hline
\end{tabular}




\begin{tabular}{|c|c|c|c|c|}
\hline & & & 52 & development \\
\hline 8 & $\begin{array}{c}\text { Price Stability, } \\
\text { (Average annual inflation } \\
\text { rate, 1990-97) }\end{array}$ & World Bank Atlas, 1999 & 52 & $\begin{array}{c}\text { Perhaps countries achieving } \\
\text { price stability put more effort } \\
\text { into bank supervision. } \\
\text { Expected effect: Positive }\end{array}$ \\
\hline 9 & $\begin{array}{c}\text { Stock Exchange } \\
\text { Capitalisation, US\$ mln }\end{array}$ & $\begin{array}{c}\text { World Bank Atlas, 1999 \& } \\
\text { Salomon Smith Barney Guide to } \\
\text { World Equity Markets,1999 }\end{array}$ & $\begin{array}{c}\text { A measure of supervisory } \\
\text { concerns outside of the } \\
\text { narrow banking system. } \\
\text { Expected effect: Positive }\end{array}$ \\
\hline 10 & $\begin{array}{c}\text { Number of Regulated } \\
\text { Banks }\end{array}$ & $\begin{array}{c}\text { OECD Bank Profitability, 1999. } \\
\text { (Excludes foreign-owned banks } \\
\text { \& domestic non-bank financial } \\
\text { institutions.) }\end{array}$ & $\begin{array}{c}\text { A measure of supervisory } \\
\text { task. Absolute effect positive, } \\
\text { but effect on ratios may well } \\
\text { be negative, because of } \\
\text { economies of scale. }\end{array}$ \\
\hline 11 & $\begin{array}{c}\text { Number of Bank } \\
\text { Branches }\end{array}$ & $\begin{array}{c}\text { OECD Bank Profitability, 1999. } \\
\text { (Excludes foreign-owned banks } \\
\text { \& domestic non-bank financial } \\
\text { institutions.) }\end{array}$ & $\begin{array}{c}\text { A measure of supervisory } \\
\text { task. Absolute effect positive, } \\
\text { but effect on ratios may well } \\
\text { be negative, because of } \\
\text { economies of scale. }\end{array}$ \\
\hline 12 & $\begin{array}{c}\text { Bank Intermediation } \\
\text { (Domestic credit } \\
\text { provided by the banking } \\
\text { system, \% of GDP, } \\
1998)\end{array}$ & $\begin{array}{c}\text { World Bank, World Development } \\
\text { Report, 1999/2000, Table 16 }\end{array}$ & $\begin{array}{c}\text { A measure of development } \\
\text { and of scale of supervisory } \\
\text { exercise. Expected effect is } \\
\text { uncertain. }\end{array}$ \\
\hline
\end{tabular}

Table 5 and the subsequent regressions are divided into two sets of variables. The first set, variables 1-9, is available from the main international data sources, for most countries, e.g. IFS, World Bank.6 The second set of variables, numbers 10-12 (Number of Regulated Banks, Number of Bank Branches, Bank Intermediation), are only available for a smaller number of respondents, mostly wealthier OECD countries. So their use would tend to remove from our sample most of the emerging/smaller respondents.

The strategy was to enter these two sets of variables sequentially, i.e. concentrating first on the common variables, no. 1-9, and then when the best fitting equation including these variables were found, adding the second set of variables to the best fitting equation, estimated at the first round. Of course, as the second set of variables was added, the sample size fell. Even so, the number of potential variables is large, especially at the first stage. Moreover, as is evident from Table 5, several of these (independent) variables are likely to be multicollinear, for example being alternative proxy measures of size or of wealth. So the first step is to examine the simple correlations between the variables in the two sets of independent variables. These simple correlations, for those cases where multicollinearity might appear to be a problem, are shown in Table 6. One response is to drop one of the variables causing multicollinearity (Greene, 1993). Where the simple correlations between pairs of variables is greater than +0.8 , only the most significant of the pair would be allowed to enter.

6 In a few cases, e.g. Bermuda Monetary Authority, mostly representing small off-shore (island) financial centres, we augmented our data with direct information from the respondents. We are grateful for their help, in such cases. 


\begin{tabular}{|l|ccccc|}
\hline & & & & & \\
\hline & 1 & - & - & - & - \\
\hline & 0.230 & 1 & - & - & - \\
\hline & 0.805 & 0.486 & 1 & - & - \\
\hline & 0.056 & 0.489 & 0.154 & 1 & - \\
\hline & 0.826 & 0.445 & 0.973 & 0.185 & 1 \\
\hline
\end{tabular}

\begin{tabular}{|l|cc|}
\hline & & \\
\hline & 1 & - \\
\hline & 0.843 & 1 \\
\hline
\end{tabular}

In the regression analysis, the ten variables are entered individually, alongside the basic equation of five variables and a constant, (CB, three supervisory role variables, GNP per head). Any variable, which appears individually significant, unless dominated by a multicollinear pair, is then kept for the next round. In this next round all the significant variables, from the first round, and the five initial basic variables, are entered simultaneously. As can be imagined, many of these variables then become insignificant. We test down from the general to the specific removing insignificant variables, whether in the initial group, or with the additional variables, one by one removing the least significant first, until we are left with our 'best' equation in which all variables are significant. In the process of doing so, as information on specific variables, for several agencies, is unavailable and the data have to be evaluated together, a significant number of supervisory bodies have to be removed from the best-fit regression equation.

The results of this exercise are shown in Table 7, where the functional dummies are in terms of supervisory role. The first two equations relate to the size of the institution, in terms of the total numbers devoted to financial supervision and the total numbers of professional experts. When a regulatory institution is a Central Bank, it tends to have more regulators (perhaps because of a stronger funding position?). A joint supervisory function or no supervisory function results in the relevant institution having less regulators and experts. Perhaps more surprisingly there seems to be no significant difference between the latter two cases.

The variable for stock exchange capitalisation enters the equations that relate to the size of the supervisory agency significantly with a positive sign. We would hypothesise that this provides an index of the need for financial supervision in the wider system, beyond and outside the monetary and banking arenas more narrowly defined. This is consistent with Levine and Zervos (1998), who find that stock markets provide different services from those of banks. So, it is hard to see any economies of scope in financial supervision. However, using a dataset on 47 countries, Levine and Zervos (1998) find that wellfunctioning stock markets promote long-run economic growth. This would suggest that the positive 
impact of stock markets on economic growth entails a (small) price in the form of extra supervisory resources needed.

There is a curious, but somewhat persistent, tendency for M2 to enter with a negative sign and M2 per head with a positive sign. A normal first reaction is that this could be due to multicollinearity, but the direct bilateral correlation between these is not high (see Table 6). We tend to assume that M2 per head is a proxy for wealth, and M2 a proxy for the size of the economy. So, perhaps the negative sign on M2 is a further indication of economies of scale, whereas subject to such economies wealthier countries do employ more regulators, experts, etc., but this remains, of course, nothing more than a conjecture.

Overall, the degree of cross-agency fit in these equations is quite impressive, explaining between half and three quarters of the inter-agency differences in ratios. Equation 3, where the dependent variable is the ratio of experts to regulators, is different, since, for example, the inclusion of the Central Bank dummy raises both the number of experts and of regulators simultaneously. Nevertheless, the OECD and stock exchange capitalisation variables enter with a positive sign. This finding suggests that relatively more experts are employed by supervisors in more developed/more complex financial systems. 


\begin{tabular}{|c|c|c|c|c|c|c|c|c|c|c|c|c|c|c|c|}
\hline$(n=71)$ & -5.69 & 2.90 & -- & -4.85 & -4.11 & -6.81 & -- & -- & -- & -5.17 & 3.08 & -- & 3.57 & -- & 0.74 \\
\hline$(n=69)$ & -6.04 & -- & -- & -3.58 & -2.97 & -6.43 & -- & -- & -- & -6.56 & 2.65 & -- & 5.35 & -- & 0.68 \\
\hline$(n=66)$ & -5.80 & -- & -- & -- & -- & -- & -- & -4.05 & -- & -- & -- & 2.97 & 3.54 & 2.33 & 0.33 \\
\hline$(n=47)$ & -7.41 & -- & -- & -- & -- & -- & -- & -2.81 & -- & -- & -- & -- & 2.12 & -- & 0.11 \\
\hline$(n=54)$ & -5.12 & -4.98 & -- & -- & -- & -- & -1.97 & -- & -- & -- & -1.80 & -- & 2.03 & -- & 0.30 \\
\hline$(n=48)$ & -11.0 & -5.82 & -- & -- & -- & -- & -- & -- & -- & -- & -- & -- & -- & -- & 0.41 \\
\hline$(n=62)$ & -8.58 & -- & -- & -- & -- & -- & -- & -- & -- & -1.92 & -- & -- & -- & 3.80 & 0.18 \\
\hline$(n=53)$ & -5.99 & 3.25 & -- & -- & -- & -- & -- & -- & -- & -- & -- & -- & -- & 2.59 & 0.17 \\
\hline
\end{tabular}

Note: Significant variables are shown, columns 2-15 refer to t-values.

\begin{tabular}{|c|c|c|c|c|c|c|c|c|c|c|c|c|}
\hline$(n=57)$ & -5.29 & 3.42 & -- & -4.72 & -4.56 & -7.34 & -- & -- & -- & $\begin{array}{l}\text { M2 } \\
\text { Stock Exchange Cap. }\end{array}$ & $\begin{array}{l}-2.57 \\
2.05\end{array}$ & 0.77 \\
\hline$(n=46)$ & -4.03 & -- & -- & -- & -- & -- & -4.19 & -3.34 & -- & Stock Exchange Cap. & 3.47 & 0.60 \\
\hline$(n=40)$ & $\begin{array}{l}-3.00 \\
\end{array}$ & -- & -- & -- & -- & -- & -- & -- & -- & \begin{tabular}{|l|} 
Price Stability \\
Stock Exchange Cap.
\end{tabular} & $\begin{array}{l}2.99 \\
2.16\end{array}$ & 0.18 \\
\hline$(n=27)$ & $\begin{array}{l}-3.31 \\
\end{array}$ & -- & -- & -- & -- & -- & 1.47 & -- & -- & -- & & 0.04 \\
\hline$(n=38)$ & $\begin{array}{l}-8.47 \\
\end{array}$ & $\begin{array}{l}-4.65 \\
\end{array}$ & - & -- & -- & -- & -- & -- & -- & -- & & 0.25 \\
\hline
\end{tabular}




\begin{tabular}{|l|c|c|c|c|c|c|c|c|c|c|c|}
\hline$(n=30)$ & -- & -3.61 & -- & - & -- & -- & -- & -- & - & - & 0.28 \\
\hline$(n=40)$ & -5.55 & -- & -- & - & -- & -- & -- & -- & -- & M2 & 0.08 \\
\hline$(n=34)$ & -- & -- & -- & - & -- & -- & -9.12 & -- & -- & - & 0.29 \\
\hline
\end{tabular}

Note: Significant variables are shown, columns 2-11 refer to $t$-values. 
As found previously (Table 4), equation 4 is quite unsuccessful in explaining inter-agency differences in the relative use of employees with previous commercial experience. There is one exception: the stock exchange capitalisation variable raises the relative number of regulators with commercial experience. This finding is intuitive. In a more complex financial system, more regulators with experience from that complex world would be needed.

The final four equations relate to the relative usage by supervisory agencies of lawyers on one hand as compared with economists and finance specialists on the other. The results are much the same as Table 4. The key determinant is whether the institution is a Central Bank, or not. Central Banks are economics-driven; non-CB regulatory institutions are lawyer-dominated. The stock exchange capitalisation variable has a positive effect on the number of lawyers hired. The impact of the economic variables is generally speaking not significant. Whether any conclusions should be drawn from the apparent significance of the positive relationship between the greater use of economists and price stability (equations 7 and 8 in Table 7), we would prefer to leave to the readers.

The next step was to take these best equations and then add the three additional variables, which we considered might be relevant, but for which we had fewer respondents. The number of bank branches never entered significantly, being dominated by its multicollinear pair, the number of banks. This would be expected as supervisors focus primarily on banks as a whole rather than individual branches. As can be seen from Table 8, both bank intermediation (measured as domestic credit provided by the banking system as a \% of GDP) and the number of banks enter significantly and negatively in equation 2 , while GNP per head ceases to be significant. We interpret this as indicating that the scale of bank intermediation and the number of banks are a better measure of likely economies of scale. GNP per head and bank intermediation are quite strongly positively correlated, as shown in Table 9.

\begin{tabular}{|l|ccc|}
\hline & & & \\
\hline & 1 & - & - \\
\hline & 0.433 & 0.768 & 1 \\
\hline & 0.424 & - \\
\hline
\end{tabular}

Otherwise, in the first two equations, in Table 8, CB, the supervisory functions, stock exchange capitalisation and M2 have much the same impact as in Table 7. The previous finding, that Central Banks hire fewer lawyers, remains. The final equation shows signs of economies of scale in the use of economists, relative to total professional experts. The significant variable, bank intermediation, is a measure of the size of the regulatory job to be done. 
Again, the regressions with supervisory duties are shown in Appendix 3 (Tables $D$ and E). As before, those institutions focusing on prudential supervision employ fewer lawyers, but they do not employ more economists. Conduct of business supervisors employ fewer economists. As before (Table 8), equations 5 and 7 in Table $E$ show signs of economies of scale in the use of lawyers and economists in supervisory bodies.

\subsection{What kind of perspective?}

This section seeks to explore what kind of supervisory skills would be useful to prevent or deal with financial crises (the main objective of prudential and systemic supervision). Using a database of some eighty-six episodes of bank insolvency, Caprio and Klingebiel (1997) find that micro-economic and macro-economic factors have figured in banking crises and that few governments have responded well to these episodes. On the micro-side, the primary causes of bank insolvency are considered to be deficient management, faulty supervision and regulation, government intervention, or some degree of connected or politically motivated lending. Recessions and large terms of trade declines figure on the macro-side. In most cases of insolvency, there is a combination of different factors (both micro and macro). Caprio and Klingebiel (1997) suggest that macro-economic factors often play an important but indirect role: a strong macro-economic climate can help erode incentives for prudent banking, whereas a downturn exposes the results of poor management. The authorities have thus to be continuously alert to the erosion of incentives in good times.

Similarly, Gonzalez-Hermosillo, Pazarbasioglu and Billings (1997) have empirically found that the degree of soundness of banks, or their probability of failure, is determined by bank-specific factors as well as by macro-economic conditions. Bank-specific variables are largely conditioned by the microprudential guidelines applicable to banks, whereas the state of the economy and the shocks affecting it define the macroprudential setting in which banks operate.

Evidence of past financial crises thus suggest that both a micro-perspective and a macro-perspective may be useful for prudential supervision (aimed at preventing problems at financial institutions or fullblown crises) and systemic supervision (dealing with crises). On the micro-side, supervisors should foster sound banking practices (e.g. proper management, adequate internal control systems). On the macro-front, they should be alert to system-wide trends (e.g. high credit growth, narrowing credit spreads) and macro-shocks affecting the financial system.7 Supervisors can then take appropriate action

7 Hellwig (1995) makes a similar point: prudential supervision ought to think in terms of system risk as well as institutional risk. Traditionally, banking supervisors assess the situation of banks by looking at each institution individually. This approach may miss important aspects of system risk exposure. 
at an early stage of the problems developing and may thus lessen the frequency or, at least, the impact of financial crises.

\subsection{Consequences for institutional structure}

What lessons can be drawn for the institutional structure of supervision? Examining past financial crises, it is found that a macro-economic perspective, besides a micro-economic perspective, may be useful for agencies responsible for prudential supervision and/or systemic stability. Economists have the capacity to analyse the impact of macro-economic trends on the financial system as a whole. 8 The empirical results in this paper indicate that an institutional setting with involvement of the central bank is more likely to produce such a macro-approach than a setting without central bank involvement. In an earlier paper (Goodhart and Schoenmaker, 1995), however, we have argued that there would be a demand for more direct political control over supervision as tax-payers are seen to be potentially liable during a crisis. This would, in turn, imply a trend towards separation between supervisory and monetary policy agencies, as it is difficult to reconcile political control over the supervisory wing of a central bank with independence for the monetary wing. The case for independence for monetary policy is well established (e.g. Cukierman, 1992; Alesina and Summers, 1993; Eijffinger and De Haan, 1996).

Another argument against direct central bank involvement in supervision is a potential creep of the central bank safety net (Goodhart, 2000). The ongoing integration and concentration in the financial sector leads to a blurring of dividing lines between different financial sectors. This used to be only the case in Europe where universal banks and financial conglomerates have existed for some time. More recently, with the adoption of the Gramm-Leach-Bliley Act (e.g. Barth, Brumbaugh and Wilcox, 2000), financial conglomerates are also allowed in the US. This integration trend would call for a cross-sector approach in supervision to maintain effectiveness as well as to prevent inefficient overlap. For reasons of time inconsistency, it would be difficult for central banks to deny credibly the availability of the lender of last resort function outside the narrowly defined banking system, while being responsible for supervising the wider financial system.

Where do these conflicting arguments about central bank involvement in supervision leave us? A possible model is an institutional setting where the central bank and the supervisory agency are put together physically with mixing of staff, but separate boards. Putting the two close to each other would allow for a blending of the necessary skills (the 'hardware') as well as the ethos and culture (the 'software'). However, as both agencies would keep their own board, decision-making and accountability are separated. The supervisory part can thus be subject to greater political control, while the monetary part can (more) credibly restrict its lender of last resort function to the core banking system. An example of

8 Economists are trained in macro and/or micro-economics. The maintained assumption is that economists would not only be alert to micro-related causes but also to macro-related causes of deteriorating soundness of financial institutions under their supervision. 
this model can be found in Finland, though not fully. After the severe financial crisis in the late eighties/early nineties, the supervisory agency responsible for banking and securities supervision was put next to the central bank, but kept its own board. The stated aim of this exercise was to get more economic skills (as well as more financial resources) into the supervisory agency, which was until then dominated by lawyers.

Another model is to ensure close co-operation between the central bank and the supervisory agency, perhaps formalised by a Memorandum of Understanding (MoU). Although separate decision-making and accountability are thus fully guaranteed, it is not clear whether such a model would facilitate a blending of skills and ethos. An example can be found in the UK. After hiving off banking supervision to the FSA, the Bank of England and the FSA (as well as HM Treasury) made an MoU. As part of this MoU, there are monthly meetings to discuss financial stability issues. Furthermore, the Bank and the FSA have agreed to send some of their employees on secondment to each other. It remains to be seen whether these arrangements are sufficient to keep the supervisory authority alert to the impact of macroeconomic factors on the financial system. It may well become pre-occupied with the financial health of individual institutions under their control and thus loose sight of the wider picture. Remember our empirical finding that agencies responsible for prudential supervision employ fewer lawyers, but do not employ more economists. This suggests that prudential supervisors on their own are less economicsdriven than central bank supervisors.

Finally, the purpose of the above-mentioned models is to maintain a link between the central bank and the prudential supervisory agency. Conduct of business is more focused on consumer protection and fair trading issues. Agencies responsible for conduct of business would need more legal skills (e.g. SEC type lawyers), as empirically found. The ethos and culture of conduct of business supervisors are thus quite different from those of their prudential colleagues. Having separate agencies responsible for prudential supervision and conduct of business may help them to focus more clearly on their respective goals.

The paper is based on a unique data set on the numbers and nature of staff employed by supervisory agencies. It is a first effort to collect detailed information on the composition of the staff at supervisory agencies. Usable data were obtained from 91 agencies covering some 57 separate countries. This new data set enables us to examine empirically for the first time what staffing and expertise institutions employ. However, the results in the paper are affected by the different ways in which supervisory agencies answered the survey questions and should therefore be interpreted cautiously.

Central banks hire more supervisors than non-central bank supervisory agencies. In particular, central banks employ more economists and fewer lawyers in their supervisory/financial stability wing than non- 
central banks. The empirical literature on financial crises (e.g. Caprio and Klingebiel, 1997) has found that both micro-economic and macro-economic factors have figured in past financial crises. This would suggest that supervision should not only be aimed at the micro-level (examining individual financial institutions) but also at the macro-level (examining macro-shocks affecting the financial system as a whole). Hellwig (1995) also stresses the importance of systemwide aspects in prudential supervision. The result that central banks hire relatively more economists would indicate that an institutional setting with direct or indirect central bank involvement is more likely to produce such a macro-approach than a setting without central bank involvement.

Next, the empirical results in this paper indicate that there are significant economies of scale in financial supervision, though this can be measured by several alternative variables (e.g. the scale of bank intermediation, GNP per head). Not surprisingly, agencies with sole supervisory responsibility will have more regulators than those with either joint or no supervisory responsibilities. An issue for further research is whether further economies of scale could be observed in countries with a mega-supervisor compared to countries with several joint supervisors. However, our database cannot produce the aggregate number of regulators in each country, as not all supervisory agencies in the countries under investigation replied to the questionnaire.

Finally, the design of financial system has a significant impact on the number and type of supervisors employed. A larger banking system will lead to relatively fewer regulators being hired, strongly indicating economies of scale. A higher stock market capitalisation, however, will lead to more regulators. There do not appear to be any economies of scope in financial supervision. Moreover, a higher stock market capitalisation raises the relative number of regulators with commercial experience as well as the relative number of lawyers. These results suggest that a more developed and complex financial system would need both more supervisors as well as more skilled ones. The positive effect of stock markets on economic growth (Levine and Zervos, 1998) seems to come at a price, albeit a small one. 
Alesina, Alberto and Lawrence Summers (1993), 'Central Bank Independence and Macroeconomic Performance: Some Comparative Evidence', Journal of Money, Credit and Banking 25, p. 151-162.

Barth, James, Dan Brumbaugh and James Wilcox (2000), 'Glass-Steagall Repealed: Market Forces Compel a New Bank Legal Structure', Journal of Economic Perspectives 14, p. 191-204.

Barth, James, Gerard Caprio and Ross Levine (1999), 'Financial Regulation and Performance: CrossCountry Evidence', Policy Research Working Paper, no. 2037, World Bank, Washington, DC.

Caprio, Gerald and Daniela Klingebiel (1997), 'Bank Insolvency: Bad Luck, Bad Policy, or Bad Banking?', in: Michael Bruno and Boris Pleskovic (eds), Annual World Bank Conference on Development Economics 1996, World Bank, Washington, DC, p. 79-104.

Courtis, Neil (ed.) (1999), How Countries Supervise Their Banks, Insurers and Securities Markets, Central Banking Publications and Freshfields, London.

Cukierman, Alex (1992), Central Bank Strategy, Credibility, and Independence: Theory and Evidence, MIT Press, Cambridge, MA.

Eijffinger, Sylvester and Jakob de Haan (1996), 'The Political Economy of Central Bank Independence', Special Papers in International Economics, no. 19, International Finance Section, Princeton University, Princeton.

Gonzalez-Hermosillo, Brenda, Ceyla Pazarbasioglu and Robert Billings (1997), 'Determinants of Banking System Fragility: A Case Study of Mexico', Staff Papers 44, IMF, Washington, DC, p.295-314.

Goodhart, Charles (2000), 'The Organisational Structure of Banking Supervision', Special Paper, no. 127, LSE Financial Markets Group, London.

Goodhart, Charles and Dirk Schoenmaker (1995), 'Should the Functions of Monetary Policy and Banking Supervision be Separated?', Oxford Economic Papers 47, p. 539-560.

Greene, William (1993), Econometric Analysis, Macmillan Publishing Company, New York, Second Edition.

Hellwig, Martin (1995), 'Systemic Aspects of Riskmanagement in Banking and Finance', Schweizerische Zeitschrift für Volkswirtschaft und Statistik 13, p. 723-737. 
Kaminsky, Graciela and Carmen Reinhart (1999), 'The Twin Crises: The Causes of Banking and Balanceof-Payments Problems', American Economic Review 89, p. 473-500.

Levine, Ross and Sara Zervos (1998), 'Stock Markets, Banks and Economic Growth', American Economic Review 88, p. 537-558.

Lindgren, Carl-Johan, Gillian Garcia and Matthew Saal (1996), Bank Soundness and Macroeconomic Policy, International Monetary Fund, Washington, DC.

Peek, Joe, Eric Rosengren and Geoffrey Tootell (1999), 'Is Bank Supervision Central to Central Banking?', Quarterly Journal of Economics 114, p. 629-653.

Rajan, Raghuram and Luigi Zingales (1998), 'Financial Dependence and Growth', American Economic Review 88, p. 559-586. 
As a follow-up to our earlier work on central banking and banking supervision1, Dirk Schoenmaker and I are conducting a study of the skilled staff, and the disciplines involved, in supervisory agencies and the supervisory/regulatory/financial stability sections of central banks. Many countries experienced severe problems in the financial sector over the last two decades. The purpose of our study is to analyse the type of staff that supervisory agencies and central banks employ in order both to prevent such problems arising and to cope with any that should still occur. We would be grateful if you could answer the following questions for your organisation:

1. What are broadly speaking the supervisory tasks of your organisation (systemic supervision, prudential supervision, and/or conduct of business)?

2. What is the make-up of the financial sector in your country? For which part is your organisation responsible (banking, securities, insurance, markets, independent advisers, etc.)?

3. Do you have a mission statement about your supervisory/regulatory/financial stability functions? Could you also provide recent speeches by the chairman about supervision?

4. Do you have an organogram specifying the (most important) units within your organisation?

5. How many people work in each unit?

6. The main focus of our study is on the units that are engaged in supervisory/regulatory/financial stability functions. Could you specify for each of these units how many experts are employed as:

- $\quad$ professional lawyers

- accountants

- $\quad$ economists

- financial experts

- $\quad$ other professional specialisations (please specify).

7. How many of these experts have had practical experience in a commercial firm?

8. What proportion of those working as middle, or senior, management in the units identified in Question 6 have had previous academic qualifications (Masters or above) in one of the professional subjects set out in Question 6 (law, accountancy, economics, finance, other)?

We hope you will be able to answer these questions. The data will be treated confidentially and will not be released to third parties, unless you authorise so. Please let us know if you need any information or clarification. We will send you a copy of our study.

Yours sincerely,

Professor Charles Goodhart

1 Goodhart, Charles and Dirk Schoenmaker (1995), 'Should the Functions of Monetary Policy and Banking Supervision be Separated?', Oxford Economic Papers 47, p. 539-560. 
The data on supervisory skills are converted into a set of ratios, where the numerator is derived from the survey (number of regulators and professional experts as well as qualifications -lawyers, economists, financial experts- and commercial experience) and the denominator is $\mathrm{M} 2$ or another survey variable. The summary statistics of these ratios are summarised in Table A and B.

\begin{tabular}{|c|c|c|c|c|}
\hline & & & & \\
\hline & 0.012508006 & 0.000975606 & $1.06042 \mathrm{E}-05$ & 0.23655914 \\
& 0.007705878 & 0.000567522 & $9.59495 \mathrm{E}-07$ & 0.24760146 \\
& 0.806681745 & 0.774193548 & 0.030927835 & 5.857142857 \\
& 0.473210905 & 0.333333333 & 0.009615385 & 4.714285714 \\
& 0.178244353 & 0.105263158 & 0.014285714 & 0.769230769 \\
& 0.216663658 & 0.162280702 & 0.02173913 & 0.769230769 \\
& 0.466069693 & 0.350925926 & 0.001655629 & 3.285714286 \\
& 0.560931867 & 0.573206986 & 0.012658228 & 1 \\
\hline
\end{tabular}

\begin{tabular}{|c|c|c|c|c|}
\hline & & & & \\
\hline & $4.29217 \mathrm{E}-05$ & 0.000204757 & 0.006202783 & 0.060388416 \\
& $1.61821 \mathrm{E}-05$ & 0.000116677 & 0.002678792 & 0.027584857 \\
& 0.109169435 & 0.364456288 & 1 & 1.793252362 \\
& 0.023118711 & 0.178030303 & 0.492647059 & 1.083333333 \\
& 0.018635957 & 0.045995671 & 0.259221311 & 0.570238095 \\
& 0.026842589 & 0.095898004 & 0.28962818 & 0.503571429 \\
& 0.053976408 & 0.144585253 & 0.642533937 & 0.933333333 \\
& 0.158217464 & 0.316176471 & 0.798170732 & 1 \\
\hline
\end{tabular}


In section 3, the impact of institutional structure is tested with the supervisory role as explanatory variable. In this appendix, regressions are repeated with the supervisory duty -systemic stability (Systemic $\mathrm{c}_{\mathrm{i}}$ ), Prudential Supervision (Prudential $\mathrm{i}_{\mathrm{i}}$ ) and Conduct of Business (Conduct $\mathrm{i}_{\mathrm{i}}$ )- as explanatory variable (Table $\mathrm{C}$ ). The impact of additional economic variables is also shown (Tables $D+E$ ).

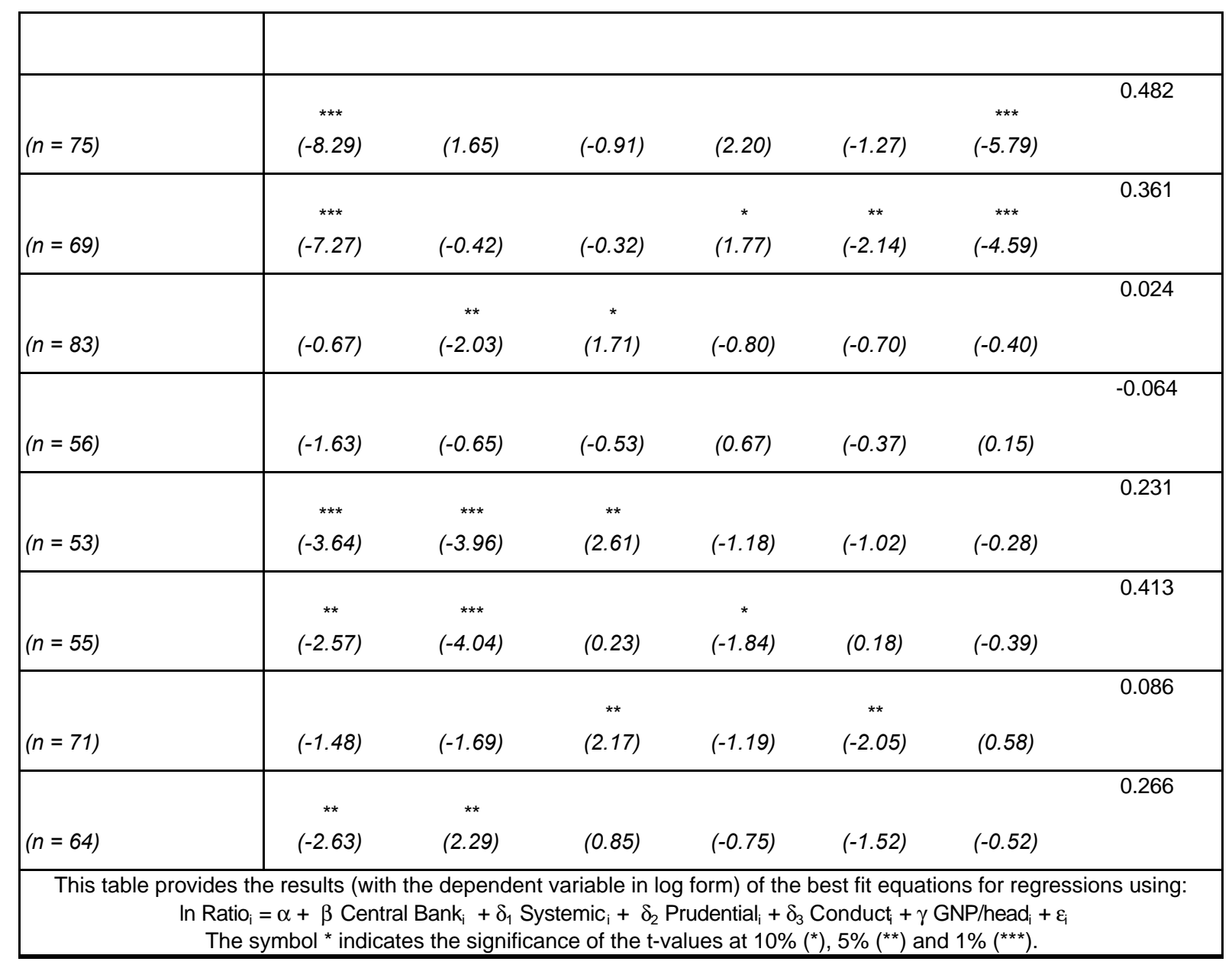




\begin{tabular}{|c|c|c|c|c|c|c|c|c|c|c|c|c|c|c|c|}
\hline$(n=69)$ & -12.4 & -- & -- & -- & -1.73 & -1.96 & -- & -- & -1.94 & -3.07 & -- & -2.13 & -- & -- & 0.57 \\
\hline$(n=64)$ & -11.3 & -- & -- & -- & -1.89 & -4.28 & -- & -- & - & -6.30 & 1.82 & -- & 4.86 & -- & 0.59 \\
\hline$(n=72)$ & -- & -3.33 & 2.00 & $\begin{array}{l}-2.45 \\
\end{array}$ & - & -- & -- & -- & -- & -4.33 & -- & -- & 3.89 & 1.86 & 0.23 \\
\hline$(n=48)$ & -2.63 & -1.88 & -- & - & - & - & -- & -3.12 & -- & -- & -- & -- & 2.23 & -- & 0.15 \\
\hline$(n=46)$ & -6.55 & -3.98 & 2.62 & -2.01 & - & - & -- & -- & -- & -2.98 & -- & -- & -- & - & 0.36 \\
\hline$(n=50)$ & -6.05 & -5.92 & -- & -1.96 & -- & -- & -- & -- & -- & -- & -- & -- & -- & -- & 0.46 \\
\hline$(n=59)$ & -6.60 & -- & -- & -- & -2.39 & -- & -- & -- & -- & -- & -- & 3.23 & -- & 1.83 & 0.19 \\
\hline$(n=51)$ & -10.0 & 4.40 & -- & -- & -- & -- & -- & -- & -- & -- & -- & -- & -- & -- & 0.27 \\
\hline
\end{tabular}

Note: Significant variables are shown, columns 2-15 refer to t-values.

\begin{tabular}{|c|c|c|c|c|c|c|c|c|c|c|c|c|}
\hline$(n=46)$ & -9.05 & -- & -- & -- & -- & -5.37 & -- & -- & -- & -- & & 0.38 \\
\hline$(n=45)$ & -7.37 & -- & -- & -- & -- & $\begin{array}{l}-4.40 \\
\end{array}$ & -- & -- & -- & $\begin{array}{l}\text { M2 } \\
\text { Stock Exchange Cap. }\end{array}$ & $\begin{array}{r}-3.77 \\
3.94 \\
\end{array}$ & 0.53 \\
\hline$(n=46)$ & -1.99 & -- & 2.10 & -- & -- & -- & -- & -- & -- & $\begin{array}{l}\text { M2 } \\
\text { Price Stability } \\
\text { Stock Exchange Cap. }\end{array}$ & $\begin{array}{l}-2.24 \\
2.00 \\
2.36 \\
\end{array}$ & 0.19 \\
\hline$(n=27)$ & -3.07 & 1.39 & -- & -- & -- & -- & -- & -- & -- & -- & & 0.04 \\
\hline$(n=29)$ & -- & -- & -- & -3.38 & -- & -- & -4.24 & -- & -- & -- & & 0.23 \\
\hline$(n=33)$ & $\begin{array}{l}-8.28 \\
\end{array}$ & $\begin{array}{l}-4.10 \\
\end{array}$ & -- & -- & -- & -- & -- & -- & -- & -- & & 0.33 \\
\hline
\end{tabular}




\begin{tabular}{|l|c|c|c|c|c|c|c|c|c|c|}
\hline$(n=36)$ & -- & -- & -- & -- & -- & -- & -8.24 & -- & -- & - \\
\hline$(n=34)$ & -8.62 & 3.75 & -- & -- & -- & -- & -- & -- & -- & -- \\
\hline
\end{tabular}

Note: Significant variables are shown, columns 2-11 refer to t-values. 